katjakranjec5@gmail.com

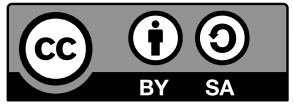

\title{
SPEAKING SUBSKILLS IN EFL COURSEBOOKS
}

\section{$1 \quad$ INTRODUCTION}

Achieving spontaneity and fluency in speaking, the objective stated in the English Grammar School Curriculum in Slovenia (Učni načrt 2008: 26), is one of the primary goals of foreign language speakers, who, in some cases, possess extensive knowledge of vocabulary and grammar structures yet lack fluency. Commonly, the reason lies in the limited ability to retrieve words or structures instantly, causing hesitation. There is a lack of automaticity, which is further exacerbated by an overarching focus on accuracy as well as translation from the mother tongue. Most importantly, students often possess inadequate knowledge and practice of speaking subskills, which are crucial to the development of fluency (Thornbury 2005: 28-29). Even though these subskills are included among speaking goals in the English Grammar School Curriculum (Učni načrt 2008: 16), they may be overlooked in teaching practice, resulting in poor acquisition of speaking subskills. This paper investigates whether EFL coursebooks sufficiently address this aspect of spoken language. To assess how well they are represented and to offer advice to high school teachers on how to approach this subject, a study is conducted on the variety and scope of specific speaking subskills in EFL coursebooks for third- and fourth-year grammar school students approved by the Slovene Ministry of Education, Science and Sport.

\section{2}

\section{LITERATURE REVIEW}

There are many authors who offer an in-depth analysis of spoken L1 English interaction based on recorded scripts, focusing, for example on intonation patterns (Stenström 1994), speech genres (Carter and McCarthy 1997) and textual analysis (Pridham 2001). Particularly relevant to L2 spoken English interaction is Brown and Yule's analysis of conversational English (1983: 10-13), in which two primary functions of speaking are discussed, i.e. transactional and interactional. The main purpose of the transactional function is to convey and transfer information, whereby the second, interactional function, is concerned with maintaining social interactions, i.e. it is listener-oriented. 
Authors studying speaking skills generally distinguish between the ability to acquire knowledge of basic units of language and the skills required to use them in communication. Brown (2004: 142) refers to the former as microskills and the latter as macroskills. Similarly, Munby (1978: 41) discusses micro and global skills.

\subsection{Knowledge and Skills that L2 Speakers Need}

The knowledge foreign language learners need to possess to speak fluently includes intercultural competence, genre knowledge, register, discourse, grammar, vocabulary, phonology and functions (Thornbury 2005: 31-37). Speech acts or functions, being most closely connected to speaking, refer to the intention behind the spoken words, such as request or advice (Thornbury 2005: 32). In speaking classes teachers should primarily focus on functions that are common in conversation, such as turn-taking, agreeing and disagreeing politely (Dörnyei and Thurrell 1994: 45). They are usually realised as short chunks of language that are difficult to predict and differ from the student's L1 language. Some authors refer to these as conversation (al) gambits (Keller and Warner 1988, Taylor 2002), while others call them conversational routines (Richards 1990: 74). Thornbury (2002, Chs. 1 and 7) offers practical ideas on how to teach lexical chunks.

Bygate (1987: 5-9) differentiates between motor-perceptive and interaction skills. Motor-perceptive skills are defined as basic skills involving "perceiving, recalling and articulating in the correct order sounds and structures of the language". These elements are devoid of context and only serve as a knowledge base. Acquiring these skills alone does not mean that one will become a fluent speaker. Motor-perceptive skills are characterised by facilitation and compensation devices (Bygate 1987: 14-21). Speaking, however, does not take place in isolation and "is jointly constructed and multi-authored" (Thornbury and Slade 2006: 15). To communicate successfully, one needs interaction skills, which are divided into routines and negotiation skills (Bygate 1987: 22-41). Routines are defined as scripts that are predictable and appear frequently in conversation, i.e. speech genres. Negotiation skills, on the other hand, help the speaker make sense of the routines so that the message is understood. They are subdivided into negotiation of meaning and management of interaction. Management of interaction encompasses skills related to agenda management and turn-taking, while negotiation of meaning incorporates skills and strategies which are applied to prevent a communication breakdown. Speakers need to be aware of the level of explicitness, i.e. how much background knowledge the interlocutor requires and how detailed the message should be, and of procedures of negotiation, i.e. words and phrases the speaker decides to use at the moment of speaking to ensure the message is understood (Bygate 1987: 22-41).

Besides speaking subskills, authors working on spoken language also discuss learner strategies of communication (Bygate 1987: 42-48, Thornbury 2005: 29-31, Goh: 2007: 
6-7). They are generally defined as strategies enabling students with insufficient linguistic knowledge to carry out a conversation.

\subsection{Direct and Indirect Approaches}

There are two main approaches to the teaching of conversation, indirect and direct. The indirect approach does not focus directly on developing speaking subskills, but assumes that engaging students in many undirected communicative activities is enough to improve their speaking skills (Richards 1990: 76-77). However, there are many drawbacks of this approach. Studies have shown that communicative tasks expose students to transactional language only, whereas interactional language, being equally or even more important, gets neglected. Another argument against this approach is that despite the fact that students may achieve relative fluency, their language still lacks accuracy and more advanced structures, such as idiomatic expressions and phrases (Richards 1990: 76-79). This approach also leads students to falsely assume that speaking skills can only be improved by more speaking (Goh 2014: 18).

The direct approach, on the other hand, focuses on teaching specific skills typical of informal conversation, such as topic management and negotiating meaning. It also incorporates intonation practice and raises awareness of the differences between formal and informal registers, short and long turns, etc. (Richards 1990: 79-81; Dörnyei and Thurrell 1994, 41). Due to the complex nature of spoken interaction, engaging the student in a variety of communicative activities is not enough to master specific speaking skills, strategies and knowledge (Burns 2012: 166).

There are many models and strategies for teaching speaking skills following the direct approach. Thornbury (2005: 41-111; 2002: Chs. 5, 6) emphasises the importance of a three-stage integration process, i.e. raising awareness of new structures, incorporation into the existing knowledge systems, and finally, autonomy. Awareness raising activities include the following steps: attention (students need to be engaged in the topic if learning is to be successful), noticing (students are made aware of new structures) and understanding (students need to understand the meaning, form and pronunciation of new structures in order to use them effectively). In contrast with the traditional PPP procedure (present, practice, produce), the second stage is adapted and referred to as appropriation. Autonomy involves the ability to use the new skill independently and in authentic situations.

Goh (2007) stresses that engaging in conversation plays a crucial role in developing automaticity. However, speaking alone is not enough to develop new skills or language. For this to happen, effective monitoring, assessment and feedback are essential. The promotion of conversation is based on the output hypothesis theory, which states that learning occurs through written or spoken production (Swain 1993: 158-163). Goh and Cohen (2014: 19-20; 1996: 4-5) also highlight the importance of employing metacognitive 
strategies in developing the learner's ability to plan and organise their conversation as well as assess their learning. Burns (2012: 172-176), likewise, proposes a general approach to teaching speaking skills, including metacognitive and awareness raising activities, input and feedback provision. Celce-Murcia et al. (1995) focus on competences and provide a model of communicative competence, consisting of discourse, linguistic, actional, sociocultural and strategic competence.

\section{3}

\section{METHODOLOGY}

The purpose of the research is to analyse the types of speaking subskills present in EFL coursebooks and how well they are taught. The analysis takes into account all twenty coursebook series approved by the Slovene Ministry of Education, Science and Sport for third- and fourth-year EFL grammar school students. The latest edition of each series is evaluated as these are most likely to be used in the future. The final two years of secondary schooling are chosen as this period is the most important one for the development of speaking skills. Students are expected to reach a high level of proficiency by the end of grammar school and an excellent use of speaking subskills is essential in order to achieve this goal.

The study uses Bygate's classification (1987), modified and supplemented by Munby's (1978) for agenda management. The following speaking subskills are observed and analysed:

- negotiation of meaning

- agenda management

The study is conducted using quantitative and qualitative research. The following teaching elements are considered:

1. Lead-in

2. Context

3. A comprehension check task

4. Number of phrases

5. Noticing activity

6. Controlled practice of meaning/form

7. Pronunciation focus

8. Authentic communicative activity

9. Location within the unit

While not all teaching elements are always necessary for learning to be successful, coursebooks should strive to include all of them. It is the teacher's choice to assess the students' knowledge and decide how detailed an activity should be to achieve specific learning goals. The analysis records whether: 
1. The lead-in task is included, which usually precedes the text in which the target structures are embedded or is placed before a related activity.

2. There is context for the target language. At least two phrases need to be embedded to be considered contextualised. If only one phrase is embedded, it is marked as " $p$ " (partly).

3. The text contains at least one comprehension check task, i.e. either an easier task (usually a gist question), which comes first, or a more detailed, follow-up one, such as comprehension questions.

4. There are at least five expressions presented for each skill. This helps to define how in depth each skill is covered. A skill which is represented by only one phrase is not recorded, as this does not enable students to master it. At a B2 level students should be able to express themselves using a variety of phrases and synonyms.

5. The activity contains a noticing task helping students to raise awareness of the target language.

6. At least some controlled practice of meaning/form is present.

7. The activity contains some kind of pronunciation focus, for instance, intonation, the pronunciation of individual sounds, sentence stress.

8. There is an authentic communicative activity included at the end, which is defined as an interactive task resembling real-life situations, i.e. communicative tasks aimed at older teenagers. An activity that is communicative but not authentic is marked as "p" (partly). For instance, if there is a speaking task in which students need to write and act out a dialogue, this is classified as partly authentic as this kind of activity is not spontaneous and interactive enough and does not resemble real-life events. Similarly, a speaking task in which two pictures are compared and speculated about is only partly authentic as this rarely happens in real life.

Even though there may be some ambiguity as to what is considered authentic, it is still useful to examine this aspect as the lack of authenticity tends to result in insufficient motivation. Furthermore, there are some coursebooks that use speaking sections to practise exam tasks, for instance, for FCE, which again may be less motivating for Slovene students unless they are preparing for the same exam.

9. Speaking subskills are presented in the first, second, third or fourth quarters of the unit. Units in the selected coursebooks are usually divided into various sections, each focusing on a specific area, for instance, reading, grammar, vocabulary building, listening, speaking, writing. Each part generally contains activities to practise receptive skills, i.e. reading or listening, which are followed by the practice of productive skills, i.e. speaking or writing. Speaking subskills are mostly covered within one of the sections, as a follow-up to a reading or listening exercise, and rarely as a separate section. This criterion is based on the premise that the location within the unit may affect whether the skill is selected for teaching in the classroom or not. 


\section{1 Negotiation of meaning}

The focus of the study was on procedures of negotiation rather than the level of explicitness, as this skill may be largely transferrable from one's mother tongue (Bygate 1987: 29-35). The following subskills are analysed:

Skills from the speaker's perspective:

- expressing the aim of the conversation in advance, e.g. One of our main goals involves ...

- checking comprehension by asking questions, e.g. Are you following me? and summarising, e.g. In a nutshell, ...

- asking for language or information that the listener cannot remember, e.g. Can you remember ...

- asking for the listener's opinion, e.g. What's your view on that?

- reacting to clarification requests by rewording, giving examples, repeating, correcting and adjusting the message according to the other person's reactions, e.g. What I mean is ...; I I'm just saying that ...

- checking agreement, e.g. I think it's really great, don't you?; It's nearly always the same, isn't it?

- dealing with interruptions, e.g. If you would just let me finish.

Skills from the listener's perspective:

- showing understanding by using non-verbal signals ${ }^{1}$ and by using verbal markers, i.e. backchannelling, e.g. Now that you mentioned that ...

- reacting to the speaker's message by showing surprise, interest, disbelief, doubt, sympathy, etc., e.g. I can't believe it!; Dreadful!

- agreeing with the speaker, e.g. True!; I couldn't agree more!

- $\quad$ showing appreciation of the speaker's message, e.g. I appreciate what you're saying.

- checking understanding of the speaker's message by summarising or paraphrasing, e.g. If I understood you correctly, ...

- $\quad$ signalling comprehension problems, e.g. Sorry, I'm not with you.

- asking for clarification, e.g. Can you run that by again, please?

- interrupting to indicate all of the above, e.g. Sorry, but ...

Skills from the speaker's and listener's perspective:

- indicating politeness by using politeness strategies, e.g. not really instead of no, disagreeing politely, e.g. I'm afraid I can't agree with you, using vague language so as not to overwhelm the listener with too much information, e.g. and so on.

1 The category of non-verbal signals is beyond the scope of this paper and will not be considered. 


\subsection{Agenda management}

These skills incorporate (Bygate 1987: 35-40):

- choosing appropriate topics

- introducing a new topic, e.g. I heard the other day that ...

- deciding on the length of the conversation

- $\quad$ starting the conversation, e.g. Let me start by saying something about ...; So, ...

- finishing the conversation, e.g. Anyway; All right

- changing and returning to previous topics, e.g. That reminds me; By the way, ...

- developing and directing the topic of conversation by using discourse markers to structure the turn, e.g. basically; actually; to show contrast, e.g. on the one hand ... on the other hand, to move on, e.g. Let's move on, shall we?

- maintaining the conversation by using fillers and vague language to gain thinking time, e.g. um; er; I mean, providing additional information and asking further questions

- $\quad$ expressing the speaker's attitude to their message, e.g. Frankly; Honestly (following Munby (1978) with some modification)

\subsection{Methodological considerations}

Although learner strategies of communication are an important set of subskills, they are not included in this research as they are mostly taught at lower levels. Similarly, turntaking skills are only partly observed as there are various classifications of such skills. There is clearly an overlap between negotiation of meaning, agenda management and turn-taking skills. For example, Richards (1990: 68) classifies reacting to the speaker's message as a turn-taking skill while Bygate (1987) classifies it as a skill in negotiation of meaning. Some other turn-taking skills according to Bygate's and Richards's classification are mostly related to non-verbal communication, intonation, gestures and the use of adjacency pairs. These skills are too broad in scope to be examined in this paper, and may also be taught at lower levels or are transferrable from the student's mother tongue.

Likewise, the only functions considered are those related to agenda management and negotiation of meaning, e.g. agreeing with the speaker and politeness strategies. These are the skills enabling both speakers to maintain a successful conversation and prevent a communication breakdown. Therefore, functions such as agreeing and disagreeing on a specific topic or statement are not analysed.

Furthermore, long turns where there is no immediate interaction between the speaker and the audience, such as presentations, are not included in the analysis. Only the interactive part is examined, e.g. responding to questions at the end of the presentation. Debates and discussions, on the other hand, are analysed as they are more interactive in nature. 
4

ANALYSIS AND DISCUSSION

\subsection{Negotiation of meaning - the most represented skills}

\begin{tabular}{|c|c|c|c|c|c|c|c|c|c|c|c|}
\hline $\begin{array}{l}\text { Negotiation } \\
\text { of meaning }\end{array}$ & $\begin{array}{l}\text { No. of } \\
\text { occur- } \\
\text { rences }\end{array}$ & Coursebook(s) ${ }^{2}$ & $\begin{array}{l}\text { Lead- } \\
\text { in }\end{array}$ & $\begin{array}{l}\text { Con- } \\
\text { text }\end{array}$ & $\begin{array}{l}\text { Com- } \\
\text { prehen- } \\
\text { sion } \\
\text { check } \\
\text { task }\end{array}$ & $\begin{array}{l}\text { Number } \\
\text { of } \\
\text { phrases } \\
\text { ( } 5 \text { or } \\
\text { more) }\end{array}$ & $\begin{array}{l}\text { Notic- } \\
\text { ing } \\
\text { activi- } \\
\text { ties }\end{array}$ & $\begin{array}{l}\text { Prac- } \\
\text { tice of } \\
\text { mean- } \\
\text { ing/ } \\
\text { form }\end{array}$ & $\begin{array}{l}\text { Pro- } \\
\text { nunci- } \\
\text { ation } \\
\text { focus }\end{array}$ & $\begin{array}{l}\text { Free } \\
\text { au- } \\
\text { thentic } \\
\text { activity }\end{array}$ & $\begin{array}{l}\text { Loca- } \\
\text { tion } \\
\text { within } \\
\text { the unit } \\
(4 / 4)^{3}\end{array}$ \\
\hline $\begin{array}{l}\text { (1) Indicating } \\
\text { politeness }\end{array}$ & 35 & $\begin{array}{l}\text { CE(1); F4(1); } \\
\text { F5(4); GB2(2); } \\
\text { GB2+(2);I(2); } \\
\text { NHAdv(1); } \\
\text { NHUI(2);NI(1); } \\
\text { NM(1);NO(2); } \\
\text { NS(2); OS(3); } \\
\text { SOLInt(2); } \\
\text { SOLUI(3);WU(6) }\end{array}$ & 31 & 29 & 23 & 25 & 26 & 10 & 7 & $\begin{array}{l}15 ; 18 \\
(\mathrm{p})^{4}\end{array}$ & $\begin{array}{l}2 \times 1 / 4 ; \\
4 \times 2 / 4 \\
17 \times 3 / 4 ; \\
12 \times 4 / 4\end{array}$ \\
\hline $\begin{array}{l}\text { (2) React- } \\
\text { ing to the } \\
\text { speaker's } \\
\text { message }\end{array}$ & 21 & $\begin{array}{l}\text { CE(3); EF(3); } \\
\text { NHAdv(1); } \\
\text { NHUI(4); NO(1); } \\
\text { OS(2); SOLInt; } \\
\text { SOLUI(1);S(1); } \\
\text { WU(2), NI(1); } \\
\text { F5(1) }\end{array}$ & 8 & 8 & 4 & 18 & 11 & 10 & 5 & $10 ; 8(p)$ & $\begin{array}{l}1 \times 1 / 4 ; \\
5 \times 2 / 4 ; \\
5 \times 3 / 4 ; \\
10 \times 4 / 4\end{array}$ \\
\hline $\begin{array}{l}\text { (3) Agreeing } \\
\text { with the } \\
\text { speaker }\end{array}$ & 13 & $\begin{array}{l}\text { EF(1); F4(1); } \\
\text { F5(1);GB2(1); } \\
\text { GB2+(1); NM(1); } \\
\text { NO(1); NS(1); } \\
\text { OS(3); SOLUI(1); } \\
\text { WU(1) }\end{array}$ & 10 & 9 & 7 & 4 & 5 & 2 & & $6 ; 7(p)$ & $\begin{array}{l}1 \times 1 / 4 ; \\
1 \times 2 / 4 \\
8 \times 3 / 4 \\
3 \times 4 / 4\end{array}$ \\
\hline $\begin{array}{l}\text { (4) Asking for } \\
\text { clarification }\end{array}$ & 11 & $\begin{array}{l}\text { CE(1); F4(1); } \\
\text { GB2(1); } \\
\text { GB2+(1);I(1); } \\
\text { NO(1);NS(1); } \\
\text { SOLUI(1); S(1); } \\
\text { WU(2) }\end{array}$ & 8 & 7 & 7 & 5 & 7 & 3 & 2 & $7 ; 2(p)$ & $\begin{array}{l}1 \times 1 / 4 ; \\
2 \times 2 / 4 ; \\
4 \times 3 / 4 ; \\
4 \times 4 / 4\end{array}$ \\
\hline $\begin{array}{l}\text { (5) Checking } \\
\text { agreement }\end{array}$ & 9 & $\begin{array}{l}\text { CE (1); EM4(1); } \\
\text { EF (1); GB2 (1); } \\
\text { NHAdv (1); } \\
\text { SOLInt (1);SOLUI } \\
\text { (1);S (1);NO(1) }\end{array}$ & 9 & 6 & 5 & 8 & 5 & 8 & 6 & $5 ; 4(p)$ & $\begin{array}{l}1 \times 1 / 4 ; \\
1 \times 2 / 4 \\
4 \times 3 / 4 \\
3 \times 4 / 4\end{array}$ \\
\hline
\end{tabular}

Table 1: The most represented skills in negotiation of meaning

$2 \quad$ Full titles are listed in the bibliography under primary sources.

$31 / 4$ stands for the first quarter; $2 / 4$ for the second quarter, etc.

$4 \quad$ (p) stands for partly.

5 The location of one activity is between two parts of the unit (2/4-3/4) and is rounded down to $2 / 4$. 
All skills in negotiation of meaning are included, the only exception being asking for language or information that the listener cannot remember. One of the main findings in the analysis is that skills from the speaker's perspective are considered less important than skills from the listener's perspective. As shown in Table 1, skills from the listener's perspective (Nos. 2, 3, 4) are most frequent. On the other hand, there is only one skill exclusively from the speaker's perspective included among the top five skills, ${ }^{6}$ i.e. checking agreement. However, if the primary speaking goal is to empower students to become confident speakers of English, it is of great importance that both types of skills are equally represented. Therefore, one implication for teaching practice is that coursebooks should be supplemented with additional materials so that both groups of skills are covered to the same extent.

In terms of how detailed each activity is, checking agreement, albeit the least frequent in the group (10\%), is covered in most detail. It has the highest percentage in terms of lead-ins (100\%), the number of phrases $(89 \%)$ and pronunciation practice $(67 \%)$. The reason for such a high percentage probably stems from the fact that all the structures presented are grammatical in nature, i.e. tag questions. On the other hand, No. 2 is covered in the least detail, followed by No. 3. The reason for this may be that, compared with other skills in the same group, Nos. 2 and 3 generally contain phrases which are slightly less complex and shorter and may therefore be covered in less detail. The study thus suggests that skills which are grammatical in nature, e.g. indirect questions, echo, reply and tag questions, are more thoroughly covered than the remaining phrases.

\subsection{Analysis of individual subskills}

\section{(1) Indicating politeness (35):}

Most activities have a lead-in (89\%), but lack practice of meaning/form (only 29\%) as well as pronunciation focus $(20 \%)$. The majority (94\%) contain a free communicative activity at the end. However, $51 \%$ of these are only partly communicative and lack authenticity. The absence of pronunciation focus and authentic tasks may be particularly problematic when it comes to expressing politeness. Appropriate pronunciation, especially intonation, plays a vital role in helping the speaker sound natural and polite. Similarly, tasks resembling real-life situations enable an easier transfer of skills from the student's mother tongue. There are four different types of this skill:

1a Disagreeing politely (14), refusing politely (2) or correcting someone politely (1), e.g. Don't get me wrong, but ...; I appreciate the offer, but ...

1b Using hedging and tentative language (9) to soften the message and appear more diplomatic, e.g. It's hard to say but ...

1c Using indirect questions (5) to tone down one's message, e.g. Could you let us know what the book is called? The activities are generally well developed (three activities fulfil all criteria).

$6 \quad$ Indicating politeness belongs to both groups. 
1d Polite requests and offers (4), e.g. Would you like me to send ...?; Would you mind ...? Some phrases also contain indirect questions, e.g. Could you tell me where the station is, please?

(2) Reacting to the speaker's message (21)

The phrases are generally short and express a wide range of emotions, e.g. interest, surprise, belief, disbelief, approval. Unlike indicating politeness (No. 1), this skill is covered less comprehensively. Lead-in activities (38\% of all cases), context (38\%) and comprehension check tasks (19\%) appear to be less frequent. The number of phrases, however, is generally above five ( $86 \%)$. The lack of detail may be due to the fact that the majority of phrases are relatively short and easy to remember, e.g. Really, How nice! Similarly, pronunciation is present in only $24 \%$ of all cases, which puts students at a disadvantage as this is an area where a focus on pronunciation is particularly important. If the speaker uses inappropriate intonation, the message may be misunderstood. Furthermore, appropriate use of intonation is also one of the objectives stated in in the English Grammar School Curriculum in Slovenia (Učni načrt 2008, p. 27). Four activities (19\%) are based around echo or reply questions. Like indirect questions in No. 1, they are more developed than the structures which are not grammatical in nature.

\section{(3) Agreeing with the speaker (13)}

Most activities have a lead-in (77\%), which is significantly higher than in No. 2 $(38 \%)$. Although all of them contain a communicative activity at the end, only $46 \%$ are authentic.

\section{(4) Asking for clarification (11)}

Similar to indicating politeness and agreeing with the speaker, context is quite frequent (64\%) compared with reacting to the speaker's message $(38 \%)$.

(5) Checking agreement (9)

All activities take the form of tag questions. Like echo questions in No. 2 and indirect questions in $1 \mathrm{c}$, they are covered relatively well. 


\subsection{Negotiation of meaning - the least represented skills}

\begin{tabular}{|c|c|c|c|c|c|c|c|c|c|c|c|}
\hline $\begin{array}{l}\text { Negotiation } \\
\text { of meaning }\end{array}$ & $\begin{array}{l}\text { No. of } \\
\text { occur- } \\
\text { rences }\end{array}$ & Coursebook(s) & $\begin{array}{l}\text { Lead- } \\
\text { in }\end{array}$ & $\begin{array}{l}\text { Con- } \\
\text { text }\end{array}$ & $\begin{array}{l}\text { Com- } \\
\text { prehen- } \\
\text { sion } \\
\text { check } \\
\text { task }\end{array}$ & $\begin{array}{l}\text { Num- } \\
\text { ber of } \\
\text { phrases } \\
\text { ( } 5 \text { or } \\
\text { more) }\end{array}$ & $\begin{array}{l}\text { Notic- } \\
\text { ing } \\
\text { acti- } \\
\text { vities }\end{array}$ & $\begin{array}{l}\text { Practice } \\
\text { of } \\
\text { mean- } \\
\text { ing/ } \\
\text { form }\end{array}$ & $\begin{array}{l}\text { Pro- } \\
\text { nun- } \\
\text { ciation } \\
\text { focus }\end{array}$ & $\begin{array}{l}\text { Free au- } \\
\text { thentic } \\
\text { activity }\end{array}$ & $\begin{array}{l}\text { Location } \\
\text { within } \\
\text { the unit } \\
(4 / 4)\end{array}$ \\
\hline $\begin{array}{l}\text { (1) Using } \\
\text { markers to } \\
\text { signal under- } \\
\text { standing }\end{array}$ & 1 & $\mathrm{NM}(1)$ & 1 & & & & & & & $1(p)$ & $1 \times 2 / 4$ \\
\hline $\begin{array}{l}\text { (2) Showing } \\
\text { appreciation of } \\
\text { the speaker's } \\
\text { message }\end{array}$ & 1 & $I(1)$ & 1 & 1 & 1 & & 1 & & & 1 & $1 \times 2 / 4$ \\
\hline $\begin{array}{l}\text { (3) Signalling } \\
\text { comprehen- } \\
\text { sion problems }\end{array}$ & 1 & $\mathrm{~F} 4(1)$ & 1 & 1 & 1 & & 1 & 1 & & 1 & $1 \times 3 / 4$ \\
\hline $\begin{array}{l}\text { (4) Expressing } \\
\text { the aim of the } \\
\text { conversation in } \\
\text { advance }\end{array}$ & 1 & $I(1)$ & 1 & 1 & 1 & & 1 & & & 1 & $1 \times 2 / 4$ \\
\hline $\begin{array}{l}\text { (5) Dealing } \\
\text { with interrup- } \\
\text { tion }\end{array}$ & 2 & $I(1), N \mid(1)$ & 2 & 2 & 2 & & 2 & & & 2 & $\begin{array}{l}1 \times 2 / 4 ; \\
1 \times 3 / 4\end{array}$ \\
\hline $\begin{array}{l}\text { (6) Checking } \\
\text { comprehen- } \\
\text { sion }\end{array}$ & 2 & GB2(1); NS(1) & 1 & 2 & 2 & 1 & 1 & 1 & 2 & 2 & $\begin{array}{l}1 \times 3 / 4 ; \\
1 \times 4 / 4\end{array}$ \\
\hline $\begin{array}{l}\text { (7) Checking } \\
\text { understanding } \\
\text { of the speak- } \\
\text { er's message }\end{array}$ & 2 & $\operatorname{NS}(1), G B 2(1)$ & 1 & 2 & 2 & & 1 & 1 & 2 & 2 & $\begin{array}{l}1 \times 3 / 4 ; \\
1 \times 4 / 4\end{array}$ \\
\hline $\begin{array}{l}\text { (8) Interrupt- } \\
\text { ing }\end{array}$ & 3 & $\begin{array}{l}\mathrm{I}(1) ; \mathrm{NI}(1) ; \\
\text { SOLUI(1) }\end{array}$ & 3 & 3 & 3 & & 3 & & & 3 & $\begin{array}{l}1 \times 2 / 4 ; \\
1 \times 3 / 4 ; \\
1 \times 4 / 4\end{array}$ \\
\hline $\begin{array}{l}\text { (9) Asking for } \\
\text { the listener's } \\
\text { opinion }\end{array}$ & 5 & $\begin{array}{l}\text { CE(1); GB2(1); } \\
\text { GB2+(1); } \\
\text { NO(1); SOLUI(1) }\end{array}$ & 4 & 4 & 4 & 2 & 3 & & 1 & $2,2(p)$ & $\begin{array}{l}3 \times 3 / 4 \\
2 \times 4 / 4\end{array}$ \\
\hline $\begin{array}{l}\text { (10) Reacting } \\
\text { to clarification } \\
\text { requests }\end{array}$ & 8 & $\begin{array}{l}\mathrm{F} 4(1) ; \mathrm{I}(2) ; \\
\text { NO(1); NS(1); } \\
\text { S(1);GB(1); } \\
\text { F5(1), }\end{array}$ & 7 & 8 & 8 & 2 & 5 & 3 & 2 & $4 ; 4(p)$ & $\begin{array}{l}2 \times 2 / 4 ; \\
4 \times 3 / 4 ; \\
2 \times 4 / 4\end{array}$ \\
\hline
\end{tabular}

Table 2: The least represented skills in negotiation of meaning

As shown in Table 2, the skills from the speaker's (Nos. 4, 5, 6, 9, 10) and listener's perspectives (Nos. 1, 2, 3, 7, 8) are equally distributed. The least developed skill is using markers to signal understanding, which has no activities except for the lead-in and communicative 
activity. The least represented teaching elements in this group are the number of phrases (only 19\% of all activities contain five or more phrases), practice of meaning/form (23\%) and pronunciation focus $(27 \%)$. The most significant difference between the most and least represented skills is thus the number of phrases, which is much lower than among the most represented skills (67\%). This indicates that the skills in the previous group are not only more frequent, but they also display a much broader range of phrases. Nevertheless, at a B2 level students should be able to display a range of phrases and all skills need to be presented and practised thoroughly.

\subsection{Agenda management}

\begin{tabular}{|c|c|c|c|c|c|c|c|c|c|c|c|}
\hline $\begin{array}{l}\text { Agenda } \\
\text { manage- } \\
\text { ment }\end{array}$ & $\begin{array}{l}\text { No. of } \\
\text { occur- } \\
\text { rences }\end{array}$ & Coursebook(s) & $\begin{array}{l}\text { Lead- } \\
\text { in }\end{array}$ & $\begin{array}{l}\text { Con- } \\
\text { text }\end{array}$ & $\begin{array}{l}\text { Compre- } \\
\text { hension } \\
\text { check } \\
\text { task }\end{array}$ & $\begin{array}{l}\text { Number } \\
\text { of } \\
\text { phrases } \\
\text { (5 or } \\
\text { more) }\end{array}$ & $\begin{array}{l}\text { Notic- } \\
\text { ing } \\
\text { activi- } \\
\text { ties }\end{array}$ & $\begin{array}{l}\text { Prac- } \\
\text { tice of } \\
\text { mean- } \\
\text { ing/ } \\
\text { form }\end{array}$ & $\begin{array}{l}\text { Pro- } \\
\text { nunci- } \\
\text { ation } \\
\text { focus }\end{array}$ & $\begin{array}{l}\text { Free au- } \\
\text { thentic } \\
\text { activity }\end{array}$ & $\begin{array}{l}\text { Location } \\
\text { within } \\
\text { the unit } \\
(4 / 4)\end{array}$ \\
\hline $\begin{array}{l}\text { (1) Main- } \\
\text { taining the } \\
\text { conversation }\end{array}$ & 17 & $\begin{array}{l}\text { CE(2); EF(1); } \\
\text { F5(2); GB2(1); } \\
\text { GB2+(2); } \\
\text { NHUI(3); NM(1); } \\
\text { NO(2); NS(1); } \\
\text { SOLInt(1);S(1) }\end{array}$ & 12 & 11 & 10 & 12 & 11 & 5 & 0 & $9 ; 6(p)$ & $\begin{array}{l}6 \times 2 / 4 \\
5 \times 3 / 4 \\
6 \times 4 / 4\end{array}$ \\
\hline $\begin{array}{l}\text { (2) Develop- } \\
\text { ing and } \\
\text { directing } \\
\text { the topic of } \\
\text { conversation }\end{array}$ & 11 & $\begin{array}{l}\text { I(1); NHUI(2); } \\
\text { NI(2); NM(1); } \\
\text { NS(1); } \\
\text { SOLInt(1); } \\
\text { WU(1); NHA- } \\
\text { dv(1), EM(5) }\end{array}$ & 8 & 8 & 7 & 6 & 8 & 3 & 2 & $4 ; 4(p)$ & $\begin{array}{l}1 \times 1 / 4 ; \\
2 \times 2 / 4 ; \\
4 \times 3 / 4 ; \\
4 \times 4 / 4\end{array}$ \\
\hline $\begin{array}{l}\text { (3) Expressing } \\
\text { the speaker's } \\
\text { attitude to } \\
\text { their message }\end{array}$ & 11 & $\begin{array}{l}\text { EF(1); F4(1); } \\
\text { GB2+(1); } \\
\text { NHAdv(1); } \\
\text { NHUI(2); NO(2); } \\
\text { SOLInt(1); S(1); } \\
\text { EM5(1) }\end{array}$ & 9 & 11 & 11 & 6 & 9 & 3 & 3 & $6 ; 3(p)$ & $\begin{array}{l}1 \times 2 / 4 \\
5 \times 3 / 4 \\
5 \times 4 / 4\end{array}$ \\
\hline $\begin{array}{l}\text { (4) Changing } \\
\text { and returning } \\
\text { to previous } \\
\text { topics }\end{array}$ & 2 & NS(1); S(1) & 2 & 2 & 2 & 1 & 2 & 1 & 0 & $1 ; 1(p)$ & $\begin{array}{l}1 \times 3 / 4 ; \\
1 \times 4 / 4\end{array}$ \\
\hline $\begin{array}{l}\text { (5) Finishing } \\
\text { the conversa- } \\
\text { tion }\end{array}$ & 2 & $\mathrm{NH}(1) ; \mathrm{NI}(1)$ & 0 & 2 & 1 & 2 & 2 & 0 & 1 & $1 ; 1(p)$ & $2 \times 4 / 4$ \\
\hline $\begin{array}{l}\text { (6) Introduc- } \\
\text { ing a new } \\
\text { topic }\end{array}$ & 2 & $\mathrm{~F} 5(1) ; 0 \mathrm{OS}(1)$ & 1 & 1 & 1 & 1 & 1 & 1 & 0 & $2(p)$ & $2 \times 3 / 4$ \\
\hline $\begin{array}{l}\text { (7) Starting } \\
\text { the conversa- } \\
\text { tion }\end{array}$ & 1 & SOLUI (1) & 1 & 0 & 0 & & & 0 & 0 & 1 & $1 \times 4 / 4$ \\
\hline
\end{tabular}

Table 3: Skills in agenda management 
Seven out of nine skills related to agenda management are present, with choosing appropriate topics and deciding on the length of the conversation not explicitly covered. The rationale may be that they are implicitly taught through other skills, such as reading or listening. As indicated in Table 3,41\% of all activities are in the fourth quarter of the unit, followed by the third quarter $(37 \%)$. In comparison, the majority of all negotiation of meaning activities (43.5\%) are found in the third quarter of the unit. This may be an indicator that skills in agenda management are considered less important, and are therefore placed further towards the end of the unit.

The most represented skills (Nos. 1-3) include

(1) maintaining the conversation with two different types:

a) using fillers and hesitation devices to gain thinking time (12), e.g. um, I guess

All 12 have a communicative activity at the end, while the majority include a lead-in (9), context (10) comprehension check tasks (9) and noticing activities (9). In contrast, none contain a pronunciation activity, which is not deemed critical as fillers are not usually stressed and do not carry meaning. Similarly, practice activities are rare (3), which may be connected to the fact that the majority of phrases have a simple structure.

b) providing additional information and asking follow-up questions (5)

This skill is much less developed than the previous one, with only one activity containing almost all teaching elements. Even though this skill is less developed it may not be so problematic, as it tends to be practised at lower levels.

(2) Developing and directing the topic of conversation (11) by using discourse markers and linking devices or phrases to show contrast, organise your turn and move the discussion forward.

(3) Expressing the speaker's attitude to their message (11)

There are two main groups:

a) comment adverbs, e.g. Unfortunately, ...

b) phrases, e.g. What's really worrying is, ...

Similarly to skill No. 2, only six out of 11 activities have five or more phrases.

The least represented skills (Nos. 4-7) are primarily concerned with transitions as opposed to the previous group, where the skills are mostly related to developing and maintaining the conversation. 


\subsection{Implications for Teaching}

In the study a total of 161 occurrences of subskills are recorded, meaning that on average only approximately eight out of 25 subskills (following Bygate's (1987) and Munby's (1978) classification) are covered in each coursebook. While it is true that one coursebook cannot include all skills, it is of vital importance that students' speaking skills are constantly assessed by their teachers and materials supplemented if there is an absence of skills in the coursebook or the lack of detail with which they are covered.

Skills in negotiation of meaning as well as agenda management are developed to a similar extent. The most and least developed teaching elements are generally attested more frequently in negotiation of meaning skills than in agenda management skills. The most developed teaching element analysed in the research is the communicative task (NM 93\% vs. AM 85\%). On the other hand, the least developed teaching elements are practice of meaning/form (AM $28 \%$ vs. NM 34\%) and pronunciation activities (AM 13\% vs. NM $23.5 \%$ ). The only exception are structures which are grammatical in nature, i.e. tag questions, echo and reply questions, indirect questions. The remaining teaching elements are generally slightly more developed in agenda management skills (lead-in: NM 76\% vs. AM 72\%; context: NM 72\% vs. AM 76\%; comprehension check tasks: NM 61\% vs. AM 70\%; activities containing five or more phrases: NM 56.5\% vs. AM 61\%; noticing activities: NM $63 \%$ vs. AM $72 \%$ ). However, regarding the variety of skills, number of occurrences and the location within the unit, skills in negotiation of meaning are better represented.

Approximately two thirds of activities in both groups, negotiation of meaning and agenda management, contain a lead-in, context and comprehension checks. This number suggests that a third of all activities lack an important teaching procedure that enables students to familiarise themselves with the context in which the target language is embedded. A lead-in is used to activate students' schemata and raise interest in the topic. If this step is missing, students are at a disadvantage, especially teenagers who often lack motivation and need additional support and encouragement. Nevertheless, this procedure can be remedied easily by the teacher by adding a short lead-in activity, e.g. posing a question or a picture related to the topic of the text and asking the students to discuss it in pairs.

In the selected coursebooks context is generally well developed. It is interactive, recorded and relatively authentic, containing features of spoken language, such as false starts, hesitations, repetitions, back channelling, and vague language. However, there are many instances where only a few target items are embedded. This makes it much harder for students to make sense of the new language. Ideally, all target language should be embedded so that the meaning and form can be guessed from the context. The solution to this problem may be to write a new script or adapt it from the coursebook by embedding additional phrases. A colleague from the same department can then help the teacher to record it. An authentic recording can also be found online and used in the classroom, although this is usually more time-consuming. Moreover, most of the reviewed books do 
not contain a script on the same page, even though this can help students notice the target language in context and guess its meaning and form. Sometimes the script is found at the end of the book, which makes it inconvenient for students. Teachers are therefore advised to provide a copy of the script for more detailed study, as students need to understand the text well before more complex structures are introduced. Therefore, it is important that an easier task (commonly focusing on the gist) is set before students listen to the recording of the text. This gives them a reason to listen, resembling what happens in real life. Before the second listening a more complex comprehension task may be set. In the study the majority of activities (two thirds) contain a comprehension check task, which is followed by a noticing activity. If one is missing, this is usually due to the lack of context.

The percentage of activities containing five or more phrases connected to one skill is relatively low. This may be due to the fact that complementary skills are sometimes taught together, e.g. interrupting and dealing with interruptions, asking for clarification and reacting to clarification requests. If there are two or more skills taught together, the number of phrases for individual skills is naturally smaller. However, in most coursebooks there are many skills introduced in the same activity (usually three or four), meaning that they are often not covered in detail. Speaking subskills are also often combined with more general functions of spoken language, e.g. chairing a debate, getting your point across. This may be a sensible decision as they all help improve speaking skills. However, it is also difficult for the student to comprehend and actively use such a variety of skills in the same speaking task, which may result in poor learning outcomes.

Similarly, noticing activities, which help students become aware of new structures before focusing on meaning and form, are relatively poorly represented in the selected coursebooks. Sometimes there is only a language box with useful expressions without any context. In coursebooks that do incorporate noticing activities consistently, there is very little variety with regard to their type. Often the same kind of activity is used throughout the book, mostly one of the following; listen to the recording and fill in the missing expressions; listen again and tick the phrases that you hear; classify the phrases according to their function. This can become somewhat monotonous, and thus teachers are advised to create their own noticing activities. If there is a transcript available, they are relatively easy to design. A number of activities can be employed, such as matching, counting, comparing, identifying, contrasting, providing transcripts with information gaps, and so on (Thornbury 2005: 48).

Practice of meaning and form is of great importance, as it helps students to practise the target language as well as memorise it so that it can later be used in a free communicative activity. As this teaching element is among the least represented ones in the observed coursebooks, it is advisable to create new practice activities, e.g. unscramble the words to form phrases (practice of form) and insert them in a dialogue (practice of meaning); listen to or read a dialogue and correct the highlighted phrases (practice of meaning or form); rewrite the sentences so that the meaning stays the same (practice of meaning and form). 
Focus on pronunciation is particularly important, as it not only helps students to memorise and automatise the target language, but also improves comprehension and enables the more natural production of language. Despite the fact that the percentage of pronunciation activities in the selected coursebooks is very low, this may not necessarily pose a problem as the target language can be modelled and drilled by the teacher. This can be done after the meaning and form have been explained, or before the final communicative task. To analyse pronunciation features, it is advisable to use the target language in simple sentences and write it on the board. Contracted forms should be used as speaking skills are practised. Next, sentence stress is marked as well as the main features of connected speech, e.g. weak forms, linking, elision, intrusion, assimilation. These features of pronunciation are particularly important to practise at advanced levels. Finally, the pronunciation of the sentences is drilled chorally, i.e. as a whole class, and individually. It is important that not too much time is spent explaining individual features of pronunciation. The focus should be on drilling the correct pronunciation.

The majority of activities contain a final communicative activity, which is a positive element as it enables students to make use of the new language in conversation. However, approximately half of the communicative tasks lack authenticity. Only 53\% of activities in negotiation of meaning and $48 \%$ in agenda management are authentic, indicating that students may not be motivated to carry out the tasks. Ideally, the activity should resemble a situation they may encounter in real life. In the reviewed coursebooks, there are a number of activities asking students to write a dialogue and perform it in front of the class. Giving students some preparation time to select key expressions and write down notes is effective, as they are given the opportunity to organise ideas and incorporate new structures into their working memory. However, by scripting the text the activity is no longer spontaneous. Speaking skills are interactive and unpredictable in nature, and some element of spontaneity needs to be present in order to enable students to use the new language independently in everyday life. Teachers are therefore advised to take a critical look at the communicative activity and, if necessary, substitute it with a more authentic task that will appeal to teenagers. It is also important that the rationale for each speaking activity is explained, i.e. why it is important to use specific expressions, and what skills are required to carry it out successfully.

Regarding the location within the unit, most activities are placed towards the end, with negotiation of meaning in the third quarter and agenda management in the fourth. In some cases, the reason may be that certain skills are connected with previous topics and are best covered towards the end of the unit. Previous sections may also provide more context, enabling students to produce more language during the speaking activity. However, the study indicates that there is a consistent tendency to place speaking subskills towards the end of the unit, suggesting that they may not be as important as the practice of grammar or reading skills, for instance, which are usually dealt with in great detail. The sections covering speaking subskills are also relatively short, i.e. almost never 
longer than one page. It is therefore important that teachers are aware of the importance of speaking subskills, and that they are prioritised and taught accordingly. Furthermore, the study indicates that, in comparison with some other textbooks, ${ }^{7}$ the coursebooks reviewed in this paper cover the speaking subskills in less detail.

\section{5} CONCLUSIONS

To determine how well skills in negotiation of meaning and agenda management are presented and developed, twenty coursebooks for third- and fourth-year grammar school students approved by the Slovene Ministry of Education, Science and Sport are reviewed in this study. In total, 161 subskills are recorded and analysed in the reviewed coursebooks, meaning the average coursebook covers approximately eight subskills, which is less than a third of all subskills. Following these findings, teachers are advised to supplement coursebooks with their own materials covering the remaining subskills if necessary. Furthermore, they should critically assess activities focusing on speaking subskills in their coursebooks and, if required, adapt them or create their own.

With regard to the number of occurrences, the location within the unit and variety of skills, negotiation of meaning skills, (helping to prevent a communication breakdown) are better represented than agenda management skills (enabling the speaker to choose an appropriate topic and organise it accordingly). However, there are no significant differences across the remaining teaching elements. Both groups generally lack focus on pronunciation and practice of meaning/form, the only exception being phrases that are grammatical in nature. A significant number of communicative activities are only partly authentic and thus not sufficiently motivating for grammar school students. The majority of sections covering subskills are placed towards the end of the unit, indicating that there is a greater likelihood that they will not be taught in the classroom. Interestingly, the most frequent listener-oriented subskills are better represented than speaker-oriented subskills.

The study gives rise to various questions in need of further research. Further topics of interest include the study of intonation in turn-taking skills, the authenticity of recordings as well as the variety of activities used to present speaking subskills across each coursebook, and assessment of language functions in EFL coursebooks. A topic that may be particularly useful for high school teachers and therefore worth researching is assessment of individual coursebooks approved by the Slovene Ministry of Education, Science and Sport, with respect to the type of speaking subskills each book contains and the level of detail with which they are covered. Furthermore, the number of occurrences and the detail with which they are developed could be compared to the number and type of objectives stated in the English Grammar School Curriculum in Slovenia (Učni načrt 2008).

$7 \quad$ Tilbury (2011), e.g. prioritises speaking subskills with varied and generally well-developed activities. 


\section{BIBLIOGRAPHY}

\section{Primary sources}

CE. CUNNINGHAM, Sarah/Peter MOOR/Jonathan BYGRAVE (2013) Cutting Edge Third Edition Upper Intermediate Students' Book with DVD-Rom (Third edition). Harlow, Essex: Pearson Education.

EF. LATHAM-KOENIG, Christina/Clive OXENDEN (2014) English File UpperIntermediate Student's Book with DVD-ROM (Third edition). Oxford: Oxford University Press.

EM4. PUCHTA, Herbert/Jeff STRANKS/Peter LEWIS-JONES (2011) English in Mind Second Edition Student's Book 4 (Second edition). Cambridge: Cambridge University Press.

EM5. PUCHTA, Herbert/Jeff STRANKS/Peter LEWIS-JONES (2012) English in Mind Second Edition Student's Book 5 (Second edition). Cambridge: Cambridge University Press.

F4. KAY, Sue/Vaughan JONES/Daniel BRAYSHAW/Beata TRAPNELL (2016) Focus 4 Students' Book. Harlow, Essex: Pearson Education.

F5. KAY, Sue/Vaughan JONES/Monica BERLIS/Heather JONES/Daniel BRAYSHAW/ Dean RUSSELL (2017) Focus 5 Students' Book. Harlow, Essex: Pearson Education. GB2. SPENCER, David (2012) Gateway B2 Student's Book. Oxford: Macmillan Publishers. GB2+. SPENCER, David (2012) Gateway B2+ Student's Book. Oxford: Macmillan Publishers.

I. WILDMAN, Jayne/Fiona BEDDALL (2014) Insight Upper-Intermediate Student's Book. Oxford: Oxford University Press.

Katalog. Katolog učbenikov za srednjo šolo. Učbeniki - gimnanzijsko izobraževanje, Angleščina kot prvi tuji jezik, 3. in 4. letnik. Ljubljana: Ministrstvo za izobraževanje, znanost in šport. 8.10.2019. https://paka3.mss.edus.si/Trubar/Javno/default.aspx .

NHAdv. SOARS, Liz and John (2003) New Headway Advanced Student's Book. Oxford: Oxford University Press.

NHUP. SOARS John and Liz (2014) New Headway Upper-Intermediate Student's Book (Fourth edition). Oxford: Oxford University Press.

NI. KAY, Sue/Vaughan JONES (2009) New Inside Out Upper Intermediate Student's Book. Oxford: Macmillan Publishers.

NM. GUDE, Kathy/Jayne WILDMAN (2007) New Matrix Upper-Intermediate Student's Book. Oxford: Oxford University Press.

NO. HARRIS, Michael/David MOWER/Anna SIKORZYNSKA (2006) New Opportunities Education for Life Upper Intermediate Students' Book. Harlow, Essex: Pearson Education.

NS. COMYNS, Carr/Jennifer PARSONS/Peter MORAN/Jeremy DAY (2012) New Success Upper Intermediate Students' Book with ActiveBook. Harlow, Essex: Pearson Education. 
OS. EVANS, Virginia/Jenny DOOLEY (2019) On Screen B2+ Student's Book. Newbury: Express Publishing.

S. KERR, Philip/Ceri JONES (2007) Straightforward Upper Intermediate Student's Book. Oxford: Macmillan Publishers.

SOLInt. FALLA, Tim/Paul A DAVIES (2017) Third Edition Solutions Intermediate Student's Book (Third edition). Oxford: Oxford University Press.

SOLUI. FALLA, Tim/Paul A DAVIES/Paul KELLY/Helen WENDHOLT/Sylvia WHEELDON (2017) Third Edition Solutions Upper-Intermediate Student's Book. Oxford: Oxford University Press.

TILBURY, Alex/Leslie Anne HENDRA/David REA/Theresa CLEMENTSON (2011) English Unlimited B2 Upper Intermediate Coursebook. Cambridge: Cambridge University Press.

WU. COLLIE, Joanne (2011) Way up Upper-Intermediate učbenik za angleščino v 3. in 4. letniku gimnazij. Ljubljana: Založba Rokus Klett.

\section{Secondary sources}

BROWN, H. Douglas (2004) Language Assessment, Principles and Classroom Practices. Harlow: Longman.

BROWN, Gillian/George YULE (1983) Teaching the Spoken Language. Cambridge: Cambridge University Press.

BURNS, Anne (2012) A Holistic Approach to Teaching Speaking in the Language Classroom. Symposium. Stockholm: University of Stockholm, 165-178.

BYGATE, Martin (1987) Speaking. Oxford: Oxford University Press.

CARTER, Ronald/Michael MCCARTHY (1997) Exploring Spoken English. Cambridge: Cambridge University Press.

CELCE-MURCIA, Marianne/Zoltan DORNYEI/Sarah THURRELL (1995) Communicative Competence: A Pedagogically Motivated Model with Content Specifications. Issues in Applied Linguistics, 6 (2). Los Angeles: Regents of the University of California, 5-35.

COHEN, Andrew D. (1996) Second Language Learning and Use Strategies: Clarifying the Issues. Minneapolis: University of Minnesota.

DÖRNYEI, Zoltán/Sarah THURRELL (1994) Teaching Conversational Skills Intensively: Course Content and Rationale. ELT Journal Volume 48/1. Oxford: Oxford University Press, 40-49.

GOH, Christine C.M. (2007) Teaching Speaking in the Language Classroom. Singapore: SEAMEO Regional Language Centre.

GOH, Christine C.M. (2014) Reconceptualising Second Language Oracy Instruction: Metacognitive Engagement and Direct Teaching in Listening and Speaking. The Asian Journal of English Language \& Pedagogy, Vol. 2. Singapore: National Institute of Education, Nanyang Technological University, 1-31. 
KELLER, Eric/Sylvia T. WARNER (1988) Conversation Gambits, Real English Conversation Practices. Hove: Language Teaching Publications.

MUNBY, John (1978) Communicative Syllabus Design, A Sociolinguistic Model for Defining the Content of Purpose-Specific Language Programmes. Cambridge: Cambridge University Press.

PRIDHAM, Francesca (2001) The Language of Conversation. London: Routledge.

RICHARDS, Jack C. (1990) The Language Teaching Matrix. Cambridge: Cambridge University Press.

SWAIN, Merrill (1993) The Output Hypothesis: Just Speaking and Writing aren't Enough. The Canadian Modern Language Review 50. Toronto: University of Toronto Press, $158-164$.

STENSTRÖM, Anna-Brita (1994) An Introduction to Spoken Interaction. Harlow: Longman Group UK.

TAYLOR, Gregory (2002) Teaching Gambits: The Effect of Instruction and Task Variation on the Use of Conversation Strategies by Intermediate Spanish Students, A. Nerenz (ed.), Foreign Language Annals, Vol. 35, No 2. Hoboken, New Jersey: Wiley-Blackwell, 171-189.

THORNBURY, Scott (2002) How to Teach Vocabulary. Harlow, Essex: Pearson Education. THORNBURY, Scott (2005) How to Teach Speaking. Harlow, Essex: Pearson Education. THORNBURY, Scott/Diana SLADE (2006) Conversation: From Description to Pedagogy. Cambridge: Cambridge University Press.

Učni načrt. Učni načrt angleščina; Gimnazija; Splošna, klasična, strokovna gimnazija; Obvezni ali izbirni predmet in matura (420 ur). Ljubljana: Ministrstvo za šolstvo in šport, Zavod RS za šolstvo, 2008.

POVZETEK

\section{GOVORNE VEŠČINE V UČBENIKIH ZA ANGLEŠKI JEZIK}

Najpogostejši cilj učencev pri pouku angleščine je, da se bodo lahko tekoče izražali v tujem jeziku in postali avtonomni govorci, ki se bodo znali naravno odzvati v skoraj vseh situacijah. Da bi dosegli ta cilj, je ključnega pomena obvladovanje govornih veščin. Cilj pričujoče raziskave je ugotoviti, kako dobro in v kolikšni meri učbeniki za angleški jezik pokrivajo posamezne veščine, in sicer pogajanja o ротепu in vodenje tem. Glede na izbrane veščine je bilo pregledanih 20 učbenikov za 3. in 4. letnik gimnazij, ki so potrjeni s strani slovenskega Ministrstva za izobraževanje, znanost in šport.

Seštevek vseh veščin kaže na dejstvo, da je $\mathrm{v}$ danih učbenikih vključenih manj kot tretjina vseh veščin. Glede na število pojavitev, umestitev znotraj učne enote in vrsto posameznih veščin so veščine, ki se nanašajo na pogajanje o pomenu, predstavljene bolje kot vodenje tem, medtem 
ko so preostali učni elementi predstavljeni v podobni meri. Analiza študije je prav tako pokazala, da večina aktivnosti ne vsebuje nalog, ki bi vadile pomen, obliko in izgovorjavo ciljnih struktur. Komunikacijske naloge so v večini primerov prisotne, vendar pogosto niso avtentične; posledično tako niso dovolj motivacijske za ciljno skupino.

Rezultati študije so namenjeni srednješolskim učiteljem in služijo kot priporočilo o tem, katere veščine, v kolikšni meri ter kako dobro so zastopane v šolskih učbenikih za angleški jezik. Podani so praktični nasveti za učenje kot pomoč učiteljem, kadar njihov učbenik ne pokriva določenih veščin oz. so te nezadostno obravnavane.

Ključne besede: govorne veščine, pogajanje o pomenu, vodenje tem, direktni pristop, učbeniki za angleški jezik

\section{ABSTRACT}

The primary goal of most EFL students is to achieve fluency in the target language and become autonomous speakers who can react naturally in most situations. To achieve this, mastery of speaking subskills is crucial. The paper aims to identify how well specific subskills, i.e. negotiation of meaning and agenda management, are represented and developed in EFL coursebooks. Twenty coursebooks approved by the Slovene Ministry of Education, Science and Sport for $3^{\text {rd }}$ and $4^{\text {th }}$ year grammar school students are reviewed.

The number of all recorded subskills in the reviewed coursebooks suggests that less than a third are covered in each coursebook. Skills in negotiation of meaning are better represented than skills in agenda management in terms of the number of occurrences, the location within the unit and variety of skills. However, there are no significant differences among the remaining teaching elements. The study also indicates that most activities do not contain practice of meaning/form and pronunciation of target phrases. Although communicative activities are mostly present, they lack authenticity and are thus not sufficiently motivating for the target group.

The results of the study can serve as a recommendation for secondary school teachers as to the type of speaking subskills, their presence in English coursebooks as well as the detail with which they are covered. Practical teaching advice is given on how the lack of variety in the selected subskills, as well as the quality of related activities can be resolved.

Keywords: speaking subskills, negotiation of meaning, agenda management, direct approach, EFL coursebooks 